\title{
Variasi Jenis dan Ukuran Bahan pada Kompos Blok Berbasis Limbah Pertanian sebagai Media Pertumbuhan Tanaman Cabai
}

\section{Type and Size Variation in Compost Block Materials from Agricultural Waste as Chili Plant Growth Media}

\author{
ELIDA NOVITA $^{1 *}$, SRI WAHYUNINGSIH ${ }^{1}$, FILA ADILIA MINANDASARI $^{1}$, HENDRA ANDIANANTA \\ PRADANA $^{2}$ \\ 1Jurusan Teknik Pertanian, Fakultas Teknologi Pertanian, Universitas Jember \\ ${ }^{2}$ Program Studi Magister Pengelolaan Sumber Daya Air Pertanian, Pascasarjana, Universitas Jember \\ Jalan Kalimantan No.37 Kampus Tegalboto, Sumbersari, Jember 68121 \\ *Email : elida_novita.ftp@unej.ac.id
}

\begin{abstract}
Agricultural waste is an organic material source. The organic matter was processed as compost. Compost block was one of composting technology developments. It has functioned as a planting medium. The type and size of raw materials are essential in the composting process. The purpose of this study was to examine variations in types and sizes of organic materials for compost blocks on the composting process and as a growth medium for chili plants. This study used a completely random design with two variables. The first variable was the variation of raw material type, i.e., coffee husk and pulp, tobacco petiole, and rice husk. The second variable was the variation of raw material size, i.e., 10, 40, and 80 mesh. The research data were analyzed using the analysis of variance test conducted with the Duncan test. The research data test show that compost from rice husks had the most $C / N$ value of 19.71. The raw material on optimally composting refers to temperature and humidity parameters as rice husk. The most effective compost block as a planting medium is a rice husk with the size of 40 mesh. The variance analysis result showed the rice husk treatment with the size material of $0.06 \mathrm{~cm}$ had significant differences in the three parameters of vegetative growth of plants, i.e., plant growth rate, leaf growth rate, and leaf area.
\end{abstract}

Keywords: composting, coffee husk and pulp, tabbaco petiole, rice husk, organic matter

\begin{abstract}
ABSTRAK
Limbah pertanian merupakan salah satu sumber bahan organik. Bahan organik tersebut berpotensi digunakan sebagai kompos. Kompos blok merupakan salah satu pengembangan teknologi pengomposan. Kompos ini digunakan sebagai media tanam. Jenis dan ukuran bahan baku berperan penting pada proses pengomposan. Tujuan dari penelitian ini adalah mengkaji variasi jenis dan ukuran pada bahanbahan organik untuk kompos blok terhadap proses pengomposan dan sebagai media pertumbuhan tanaman cabai. Penelitian ini menggunakan rancang acak lengkap dengan dua variabel. Variabel pertama adalah jenis bahan baku kompos meliputi kulit kopi, limbah tangkai daun tembakau, dan sekam padi. Variabel kedua adalah variasi ukuran dengan menggunakan ayakan 10, 40, dan 80 mesh. Data hasil pengukuran dianalisis menggunakan uji Analysis of Variance yang dilanjutkan dengan uji Duncan. Hasil pengujian unsur hara menunjukkan bahwa kompos dari sekam padi memiliki nilai $\mathrm{C} / \mathrm{N}$ sebesar 19,71. Pengomposan bahan yang berjalan optimal berdasarkan parameter suhu dan kelembaban adalah sekam padi. Kompos blok yang paling efektif sebagai media tanam berdasarkan parameter laju jumlah daun adalah limbah sekam padi ukuran 40 mesh. Hasil uji Analysis of Variance menujukkan bahwa pelakuan ukuran sekam padi sebesar $0,06 \mathrm{~cm}$ memiliki perbedaan nyata terhadap tiga parameter pertumbuhan vegetatif tanaman, yaitu laju tinggi tanaman, laju jumlah daun, dan luas daun.
\end{abstract}

Kata Kunci : pengomposan, kulit buah kopi, limbah tangkai tembakau, sekam padi, bahan organik

\section{PENDAHULUAN}

\subsection{Latar Belakang}

Kopi, tembakau, dan padi merupakan beberapa komoditi unggulan di Indonesia. Ketiga komoditi tersebut cukup potensial dikembangkan di Indonesia dengan produktivitas tanaman kopi, tembakau, dan padi secara berurutan yaitu 0,725 ton/ha ${ }^{(1)}, 1,07$ ton/ha(2), dan 5,2 ton/ha ${ }^{(3)}$. Pengolahan turunan dari buah kopi, daun tembakau, dan padi akan menghasilkan limbah padat. Merujuk pada kajian dari Novita et al. ${ }^{(4)}$, pengolahan buah kopi akan menghasilkan limbah kulit kopi hampir $42 \%$. Adapun produksi limbah padat berupa batang daun tembakau dari hilirisasi tanaman 
tembakau sebesar $11 \%{ }^{(5)}$. Sekam padi dari hasil penggilingan padi sebesar $20 \%{ }^{(6)}$. Bahan-bahan organik dari aktivitas pertanian relatif potensial dari segi jumlahnya. Akan tetapi pemanfaatannya untuk usaha pertanian hanya $30-40 \%{ }^{(7)}$. Oleh sebab itu diperlukan upaya pemanfaatan lebih lanjut limbah padat tersebut.

Limbah-limbah dari hasil aktivitas pertanian relatif masih mengandung bahan organik. Merujuk pada hasil penelitian Novita et al. (4), limbah kulit kopi mengandung unsur hara nitrogen sebesar $1,94 \%$, fosfor $0,28 \%$, dan kalium 3,61\%. Adapun kandungan bahan organik pada tembakau sebesar $7-25 \%(8)$. Menurut Demir dan Gulser ${ }^{(9)}$, kandungan $\mathrm{C}$ dan $\mathrm{N}$ pada sekam padi secara berurutan sebesar $46,303 \%$ dan 0,376\%. Berdasarkan kandungan haranya, ketiga bahan tersebut berpotensi dimanfaatkan sebagai bahan baku kompos.

Kompos merupakan produk hasil dekomposisi yang bersifat stabil dari bahan organik baik secara anaerobik maupun aerobik dengan bantuan mikroorganisme pengurai(10). Dekomposisi tersebut, umumnya bersifat terkontrol dan alami yang akan mengubah biomassa segar menjadi kompos yang dapat memperbaiki kualitas tanah dan nutrisi pertumbuhan tanaman ${ }^{(11,12)}$. Secara umum, limbah pertanian dan domestik dapat dimanfaatkan sebagai kompos karena mengandung subtrat seperti lignin, selulosa, dan hemiselulosa ${ }^{(12)}$. Pengembangan teknologi pengomposan berupa lamanya waktu dekomposisi dan kualitas bahan organik berpotensi untuk diaplikasikan sebagai pupuk organik.

Kompos blok merupakan salah satu inovasi untuk mengaplikasikan pupuk organik untuk media tanam. Kompos blok berbentuk silinder padat yang umumnya digunakan sebagai media pembibitan tanaman. Kompos blok difungsikan sebagai media tanam, khususnya digunakan sebagai media tanam untuk pembibitan. Aplikasi kompos blok dari kulit buah kopi mampu mendukung pertumbuhan vegetatif tanaman cabai ${ }^{(4,13)}$.

Pada beberapa penelitian, pembuatan kompos blok tidak mempertimbangkan ukuran bahan baku. Ukuran bahan baku yang digunakan sangat penting pada proses pengomposan. Hal ini didukung oleh hasil penelitian Pandebesie dan Rayuanti(13), semakin kecil ukuran potongan bahan maka semakin cepat pula proses pembusukan kompos. Oleh sebab itu, beberapa hal yang perlu diperhatikan dalam pembuatan kompos blok menggunakan bahan organik dari limbah padat pertanian yaitu variasi bahan karakteristik hara dan ukuran bahan. Jenis bahan memiliki peran penting dalam penyediaan substrat bagi pengomposan bahan organik(12). Kualitas $\mathrm{C} / \mathrm{N}$, kadar air, dan $\mathrm{pH}$ yang memenuhi standar kompos dapat mengoptimalkan pertumbuhan tanaman baik vegetatif maupun generatif. Merujuk pada penelitian Zulkarnain(14), jenis bahan kompos berpengaruh terhadap kualitas kompos dan berpengaruh terhadap perbaikan sifat fisik-kimia tanah dan produktivitas tanaman tebu. Adapun variasi ukuran biomassa berpengaruh pada kadar air kompos yang berdampak pada pertumbuhan vegetatif tanaman ${ }^{(15-17)}$

\subsection{Tujuan Penelitian}

Unsur hara $\mathrm{C}, \mathrm{N}$ dan $\mathrm{C} / \mathrm{N}$ rasio sangat dibutuhkan bagi suatu media tanam. Fungsi nitrogen adalah untuk meningkatkan pertumbuhan tanaman, menyediakan pertumbuhan daun (daun tanaman menjadi lebih hijau). Karbon (C) berfungsi sebagai komponen dasar molekuler karbohidrat, protein, lemak dan asam nukleik(18). Tujuan dari penelitian ini yaitu membandingkan kandungan unsur hara kompos blok dengan standar teknis pupuk organik berdasarkan parameter $\mathrm{C}, \mathrm{N}$, dan $\mathrm{C} / \mathrm{N}$, menganalisis pengaruh variasi jenis dan ukuran bahan organik kompos blok terhadap perubahan parameter suhu, $\mathrm{pH}$, dan kelembaban selama pengomposan serta membandingkan variasi pelakuan kompos blok terhadap parameter pertumbuhan vegetatif tanaman cabai.

\section{METODE}

\subsection{Waktu dan Tempat}

Pengambilan data dilakukan pada tanggal 1 September 2018 hingga 17 November 2018. Adapun uji coba kompos blok pada tanaman cabai dilakukan di green house Laboratorium Teknik Pengendalian dan Konservasi Lingkungan Jurusan Teknik Pertanian Fakultas Teknologi Pertanian Universitas Jember.

\subsection{Preparasi Bahan dan Peralatan Penelitian}

Bahan yang digunakan dalam penelitian ini diantaranya yaitu limbah kulit kopi, limbah batang tembakau, dan limbah sekam padi. Setelah dikeringkan, ketiga bahan tersebut digiling, dihaluskan, dan diayak menggunakan ayakan 10, 40, dan 80 mesh dengan ukuran secara berurutan yaitu $0,245 \mathrm{~cm} ; 0,06 \mathrm{~cm}$; serta $0,03 \mathrm{~cm}$. Bahan tambahan yang digunakan dalam proses pembuatan kompos yaitu kotoran ternak (kambing), EM4, molases, air, tanah, kanji sebagai perekat.

Adapun alat yang digunakan dalam penelitian ini terdiri atas $\mathrm{pH}$ meter merk Senz, termometer, timbangan digital Ohaus, higrometer, ayakan manual 10, 40, 80 mesh, 
ember atau bak, plastik besar, pengepres kompos blok, hand sprayer, dan mesin penggiling.

\subsection{Pengomposan dan Pengukuran Unsur Hara}

Prosedur penelitian terdiri atas persiapan bahan, pengomposan, pencetakan kompos blok, dan aplikasi kompos blok sebagai media pertumbuhan tanaman. Pengeringan dan pengecilan ukuran bahan merupakan tahap preparasi bahan. Pengeringan bahan baku (limbah kulit kopi, limbah batang tembakau, limbah sekam padi), pengecilan ukuran dengan cara dicacah menjadi ukuran yang lebih kecil kemudian digiling serta dilakukan pengayakan menjadi tiga jenis ukuran diantaranya yaitu 10 mesh, 40 mesh, dan 80 mesh dengan kode secara berurutan A, B, dan C. Adapun kode Limbah Kulit Kopi, Limbah Batang Tembakau (tangkai daun tembakau), dan Limbah Sekam Padi secara berurutan yaitu LKM, LTM, dan LPM.

Selanjutnya akan dilakukan pengukuran kadar karbon (C) / nitrogen (N) awal pada limbah kulit kopi, limbah batang tembakau, limbah sekam padi, dan tanah. Pengukuran kadar karbon (C) menggunakan metode Walkey and Black serta pengukuran nitrogen total $(\mathrm{N})$ menggunakan metode spektrofotometrik ${ }^{(12)}$. Setelah dilakukan pengukuran kadar $\mathrm{C} / \mathrm{N}$ pada limbah dan contoh tanah, maka dilajutkan dengan pecampuran bahan baku yaitu $1 \mathrm{~kg}$ limbah kulit kopi/tembakau/sekam padi, $20 \mathrm{ml}$ EM4, $1 \mathrm{sdm}$ molases, dan $1 \mathrm{~kg}$ kotoran hewan dan dilakukan proses pengomposan selama 1 minggu. Merujuk pada kajian oleh Novita et al. ${ }^{(4)}$, pembuatan kompos blok dari kulit kopi dengan perbandingan 1 (kulit kopi): 1 (kotoran ternak) selama 1 minggu, dapat menghasilkan kompos yang matang. Parameter yang diamati dalam proses pengomposan diantaranya yaitu $\mathrm{pH}$, suhu, dan kelembaban. Setelah 1 minggu pengomposan bahan dilakukan pengukuran $\mathrm{C} / \mathrm{N}$. Pengomposan bahan organik akan menghasilkan kompos dalam kondisi stabil(11).

\subsection{Pencetakan Kompos Blok}

Setelah kompos matang maka dilanjutkan dengan pencampuran kompos, tanah, dan tepung tapioka Adapun perbandingan kompos dengan tanah hutan yaitu 1:1. Tepung tapioka yang digunakan adalah kanji yang dipanaskan dengan air bertujuan untuk merekatkan kompos blok. Cara pembuatan perekat tersebut yaitu $250 \mathrm{~g}$ tepung tapioka dilarutkan dalam $300 \mathrm{~mL}$ air kemudian dimasukkan ke dalam $700 \mathrm{~mL}$ air mendidih dengan api kecil dan diaduk hingga mengental. Dalam 250 gram tepung tersebut yang dilarutkan dengan $1 \mathrm{~L}$ air dapat digunakan untuk perekat 13 kompos blok ${ }^{(4)}$. Selanjutnya dilakukan pengepresan. Visualisasi kompos blok dapat dilihat pada Gambar 1.

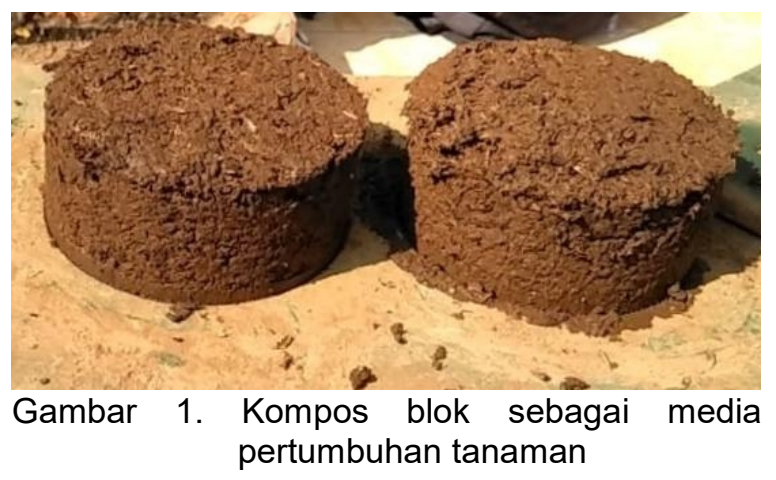

\subsection{Aplikasi Kompos Blok pada Tanaman Cabai}

Penanaman dilakukan dengan cara melubangi kompos blok sedalam $12 \mathrm{~cm}$. Aplikasi kompos blok dilakukan pada tanaman yang berumur 7 hari dengan pengamatan parameter pertumbuhan vegetatif tanaman yaitu tinggi tanaman, jumlah daun, luas daun diukur dengan menggunakan kertas millimeter ${ }^{(19)}$ Pengamatan dilakukan setiap hari pada pagi hari selama 2,5 bulan. Luas daun dapat dihitung dengan Persamaan 1. Pengukuran diameter batang dapat dihitung dengan cara menggunakan prinsip diameter lingkaran. Diameter batang dapat dihitung dengan Persamaan 2. Selanjutnya dilakukan pengukuran laju pertumbuhan vegetatif tanaman dengan Persamaan 3.

Luas Daun $=\mathrm{n} \times \mathrm{Lk}$

$\mathrm{n}=$ Jumlah kotak $\mathrm{Lk}=$ Luas tiap kotak

$D=\frac{K \text { Lingkaran }}{\pi}$

K Lingkaran = Keliling Lingkaran

$\mathrm{D}=$ Diameter $\quad \pi=$ Phi $(3,14)$

Laju pertumbuhan $=\frac{\ln (P \text { akhir }-P \text { awal })}{T \text { akhir }-T \text { awal }}$

$\mathrm{P}$ awal $=$ Nilai parameter awal;

$\mathrm{P}$ akhir $=$ Nilai parameter akhir

T awal = waktu pengukuran awal;

$\mathrm{T}$ akhir = waktu pengukuran akhir

\subsection{Analisis Statistik}

Data yang diperoleh dari hasil penelitian selanjutnya pertama akan dianalisis menggunakan statistik uji ANOVA (Analysis of Variance) dua arah ${ }^{(20)}$. Terdapat 3 ulangan pada setiap perlakuan atau pengujian. Hal tersebut bertujuan untuk mengetahui komparasi efektifitas tiga jenis kompos terhadap pertumbuhan vegetatif tanaman. Hipotesis yang digunakan yaitu $\mathrm{HO}$ atau tidak ada perbedaan 
yang signifikan antara ukuran dan bahan pada variabel proses pengomposan dan $\mathrm{H} 1$ adanya perbedaan yang siginifikan antara ukuran dan bahan pada variabel proses pengomposan. Ketika hasil dari pengujian ANOVA diperoleh kesimpulan $\mathrm{H} 1$ diterima maka akan dilakukan uji lanjutan menggunakan DMRT (Duncans Multiple Range Test) untuk mengetahui komparasi efektifitas tiga jenis kompos terhadap pertumbuhan vegetatif tanaman. Data yang diolah menggunakan Uji ANOVA yaitu data yang terdistribusi normal. Sedangkan data yang tidak terdistribusi normal diolah menggunakan uji chi square. Hasil pengolahan data disajikan dalam bentuk grafik garis kecepatan pengomposan dan laju pertumbuhan vegetatif tanaman. Hasil pengolahan data disajikan dalam bentuk grafik garis kecepatan pengomposan dan laju pertumbuhan vegetatif tanaman.

\section{HASIL DAN PEMBAHASAN}

\subsection{Potensi Unsur Hara C, N, dan Ratio C/N Limbah Organik sebagai Bahan Baku Kompos}

Kriteria kandungan hara $\mathrm{C}$ dan $\mathrm{N}$ berpengaruh terhadap tingkat kesuburan tanah. $\mathrm{Di}$ sisi lain, rasio $\mathrm{C} / \mathrm{N}$ akan berpengaruh terhadap kualitas tanah guna mendukung pertumbuhan tanaman baik vegetatif maupun generatif. Merujuk pada hasil investigasi Setyorini et al. ${ }^{(10)}$, kadar $\mathrm{N}$ tanah yang baik berkisar antara 0,1-0,2\%. Kadar $\mathrm{N}$ ini digunakan sebagai salah satu rujukan kandungan $\mathrm{N}$ pada pupuk kompos. Adapun kandungan C-organik dan $\mathrm{C} / \mathrm{N}$ pada kompos dalam kategori baik berdasarkan Peraturan Menteri Pertanian Nomor 70 tahun 2011 secara berurutan sebesar > 15\% dan 15 - 25. Konsekuensi yang akan timbul jika kandungan unsur hara yang dihasilkan tidak memenuhi dari standar tersebut, maka kualitas tanah dan kompos dalam kategori rendah berdasarkan parameter $\mathrm{C}, \mathrm{N}$, dan $\mathrm{C} / \mathrm{N}$. Pengukuran $\mathrm{C}$ dan $\mathrm{N}$ hanya dilakukan pada bahan baku. Hal ini dilakukan mengingat kotoran hewan diasumsikan sebagai sumber mikroorganisme pengurai alami yang sudah aktif. Merujuk pada hasil penelitian Novita et al. ${ }^{(4)}$, kotoran sapi menjadi salah satu sumber mikroorganisme pengurai biomassa.

Hasil uji pupuk pupuk kompos dan tanah memiliki kandungan unsur hara yang beragam. Berdasarkan hasil peneitian diketahui bahwa kandungan nilai $\mathrm{C}$ organik baik pada limbah maupun pada tanah tidak memenuhi standar yang ditetapkan (15\%). Akan tetapi semua bahan limbah memiliki kandungan $\mathrm{C}$ organik lebih tinggi dibandingkan dengan kandungan $\mathrm{C}$ organik pada tanah sebesar $4,31 \%$. Nilai C pada limbah batang tembakau, kulit kopi, dan sekam padi secara berurutan yaitu 14,59\%; 14,56\%; dan $12,32 \%$. Kandungan C organik tertinggi adalah limbah tangkai tembakau. Tingginya kandungan $\mathrm{C}$ organik pada batang tembakau diduga adanya kandungan glukosa, protein, dan hemiselulosa ${ }^{(8)}$. Akan tetapi, kondisi ini tidak serupa dengan kandungan unsur $\mathrm{N}$ pada tanah dan kompos.

Semua nilai $\mathrm{N}$ baik yang terkandung pada limbah organik maupun tanah telah memenuhi standar $(0,1 \%-0,2 \%)$ dan tergolong relatif tinggi. Kandungan $\mathrm{N}$ pada sampel tanah sebesar $0,35 \%$. Adapun unsur hara $\mathrm{N}$ yang terkandung pada limbah tangkai tembakau, kulit kopi, dan sekam padi secara berurutan yaitu 1,10\%; $1,25 \%$; dan $0,76 \%$. Kulit kopi memiliki kandungan unsur hara $\mathrm{N}$ yang lebih tinggi daripada bahan organik lainnya(21). Kandungan protein yang tinggi pada kulit buah kopi diduga mengakibatkan nilai nitrogennya tinggi pula. Kandungan nilai $\mathrm{N}$ tertinggi yaitu terdapat pada limbah kulit kopi senilai $1,25 \%$, Nisbah nilai C dan $\mathrm{N}$ tanah maupun kompos dalam kualitas baik direpresentasikan dalam $\mathrm{C} / \mathrm{N}$.

Tabel 1. Kandungan C/N Kompos Blok

\begin{tabular}{lc}
\hline $\begin{array}{c}\text { Bahan Baku Kompos } \\
\text { Blok }\end{array}$ & $\begin{array}{c}\text { Rasio C/N Kompos } \\
\text { Blok }\end{array}$ \\
\hline $\begin{array}{l}\text { Kulit Buah Kopi } \\
\text { Limbah Tangkai Daun }\end{array}$ & 16,17 \\
Tembakau & 17,92 \\
Sekam Padi & 19,71 \\
\hline
\end{tabular}

Nilai $\mathrm{C} / \mathrm{N}$ dari ketiga bahan organik tersebut beragam. Rasio $\mathrm{C} / \mathrm{N}$ yang memenuhi standar kompos yang baik (15-25) adalah kompos dari sekam padi tembakau dengan nilai 16,21. Adapun kandungan $\mathrm{C} / \mathrm{N}$ yang tidak memenuhi standar kompos dari limbah batang tembakau dan kulit kopi secara berurutan bernilai 13,26 dan 11,65. Hasil pengukuran $\mathrm{C} / \mathrm{N}$ contoh tanah dalam kategori rendah karena bernilai 12,31. Unsur hara $\mathrm{C}, \mathrm{N}$, dan rasio $\mathrm{C} / \mathrm{N}$ sangat dibutuhkan bagi suatu media tanam. Fungsi nitrogen adalah untuk meningkatkan pertumbuhan tanaman dan menyediakan pertumbuhan daun (daun tanaman menjadi lebih hijau). Karbon (C) berfungsi sebagai komponen dasar molekuler karbohidrat, protein, lipid, dan asam nukleat(22).

Adapun nilai $\mathrm{C} / \mathrm{N}$ kompos hasil dekomposisi kulit kopi, limbah tangkai tembakau, dan sekam padi memenuhi standar teknis minimal pupuk organik. Nilai ini dapat dilihat pada (Tabel 1). Nilai $\mathrm{C} / \mathrm{N}$ yang stabil menjadi salah satu indikasi, bahwa kompos sudah matang dan terdapat 
perombakan polimer menjadi senyawa yang lebih sederhana(12).

\subsection{Perbedaan Perlakuan dan Jenis Bahan Terhadap Parameter Proses Pengomposan}

\subsubsection{Suhu}

Suhu berperan dalam proses dekomposisi suatu bahan organik pada pengomposan.
Proses dekomposisi akan berlangsung lebih cepat apabila suhu pada pengomposan lebih tinggi daripada suhu lingkungan (kondisi tropis) sehingga akan semakin banyak konsumsi oksigen. Proses perombakan bahan organik akan mengakibatkan suhu pengomposan berfluktuasi. Temperatur optimal dalam proses pengomposan yaitu $35-60{ }^{\circ} \mathrm{C}^{(23)}$. Perubahan suhu yang dialami sampel limbah kulit kopi, limbah batang tembakau, dan limbah sekam padi dapat dilihat pada Gambar 2.

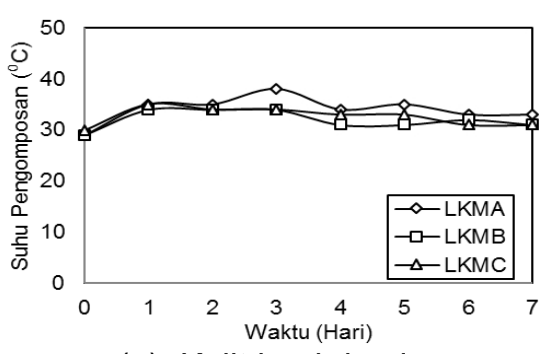

(a) Kulit buah kopi

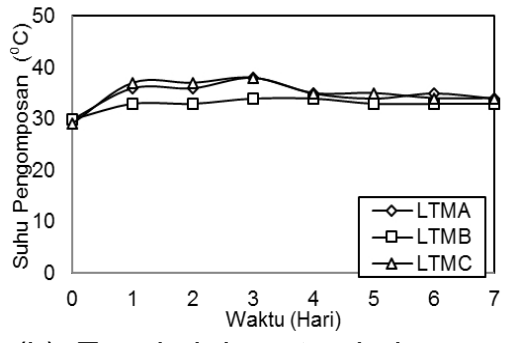

(b) Tangkai daun tembakau

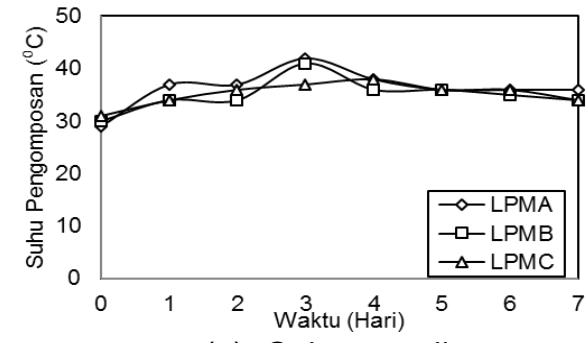

(c) Sekam padi

Gambar 2. Perubahan suhu pengomposan

Suhu pengomposan mengalami fluktuasi selama proses. Fluktuasi suhu mengindikasikan penguraian bahan organik oleh mikroorganisme secara anaerobik ${ }^{(13)}$. Pada indikator suhu terdapat dua capaian fase yaitu fase termofilik $\left(40-65^{\circ} \mathrm{C}\right)$ dan fase mesofilik $\left(28-31^{\circ} \mathrm{C}\right)$. Berdasarkan gambar 2 terdapat beberapa sampel yang menunjukkan nilai suhu tinggi kemudian menurun, dan kembali naik. Perubahan suhu tersebut dikarenakan adanya pelepasan energi dalam bentuk panas pada saat perombakan bahan organik. Selain itu proses pembalikan yang dilakukan pada saat fermentasi kompos mengakibatkan temperatur turun dan kemudian kembali naik. Pengadukan atau pembalikan bahan dilakukan setiap hari selama 1 minggu pengomposan. Hal tersebut sesuai dengan pernyataan Pandebesie dan Rayuanti ${ }^{(13)}$, pembalikan dapat mengakibatkan suhu kompos fluktuatif. Adapun faktor lain yang mempengaruhi suhu pengomposan adalah tumpukan bahan. Bahan yang digunakan dalam penelitian ini, tidak terlalu banyak hanya mencapai $1 \mathrm{~kg}$. Jika jumlah bahan yang akan didekomposisi banyak dan menyebabkan timbunan maka berpotensi meningkatkan suhu hingga tahap termofilik ${ }^{(24)}$.

Meskipun semua sampel mencapai suhu optimum pengomposan, hanya sampel limbah sekam padi ukuran 10 mesh dan 40 mesh yang mencapai fase termofilik yang dicapai pada hari ketiga. Adapun limbah sekam padi ukuran 80 mesh, sampel limbah kulit kopi dan limbah batang tembakau ukuran 10 mesh, 40 mesh, dan 80 mesh hanya mencapai fase mesofilik. Konsekuensi ini timbul akibat terlalu sedikitnya pembuatan kompos sehingga menghasilkan tumpukan yang terlalu rendah pada proses fermentasi. Rendahnya tumpukan tersebut mengakibatkan bahan kompos mudah kehilangan panas sehingga tidak tercapai fase termofilik. Menurut Suswantati dan Widyaningrum $^{(25)}$, kondisi mesofilik lebih efektif dalam proses pengomposan dikarenakan aktifitas mikroorganisme didominasi protobakteri dan fungi.

\subsection{2 $\mathrm{pH}$}

Pengomposan akan mengakibatkan perubahan derajat keasaman pada bahan tersebut. $\mathrm{pH}$ optimum proses pengomposan yaitu $6,5-7,5^{(23)}$. Perubahan $\mathrm{pH}$ yang dialami pada sampel kulit kopi, batang tembakau, dan sekam padi dapat dilihat pada Gambar 3. Nilai $\mathrm{pH}$ pada proses pengomposan mengalami peningkatan mulai dari hari ke-0 hingga hari ketujuh. Akan tetapi pada hari-hari terakhir pengomposan terdapat beberapa nilai $\mathrm{pH}$ yang konstan dan mencapai nilai $\mathrm{pH}$ 7. Pada sampel limbah sekam padi ukuran 40 mesh dan 80 mesh menunjukkan nilai $\mathrm{pH} 6,8$. Secara umum semua sampel kompos dari ketiga limbah hasil dari aktivitas pertanian dapat mencapai $\mathrm{pH}$ yang optimum $(6,5-7,5)$.

Peningkatan nilai $\mathrm{pH}$ pada pengomposan diduga terjadi akibat penguraian protein menjadi amonia pada bahan. Merujuk pada kajian Suswantati dan Widyaningrum ${ }^{(25)}$, perubahan nilai $\mathrm{pH}$ pada pengomposan terjadi akibat perombakan karbohidrat dan protein menjadi senyawa yang lebih sederhana. Pada hari (0) awal pengomposan $\mathrm{pH}$ bernilai rendah yang mengindikasikan dalam kondisi asam. Konsekuensi ini timbul akibat terbentuknya 
asam - asam organik sederhana dari proses perombakan karbohidrat. Pada hari - hari berikutnya nilai $\mathrm{pH}$ akan meningkat akibat terurainya protein dan terjadi pelepasan ammonia. Selanjutnya $\mathrm{pH}$ akan mencapai nilai netral yang menandakan matangnya kompos. Nilai $\mathrm{pH}$ pengomposan semakin tinggi seiring dengan bertambahnya hari pengomposan hingga mencapai nilai $\mathrm{pH}$ optimum ${ }^{(23)}$.

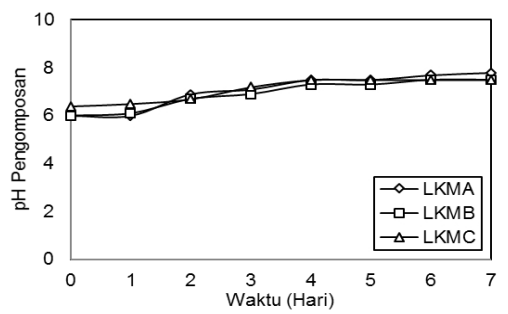

(a) Kulit buah kopi

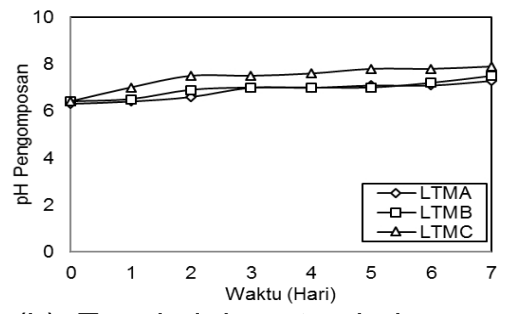

(b) Tangkai daun tembakau

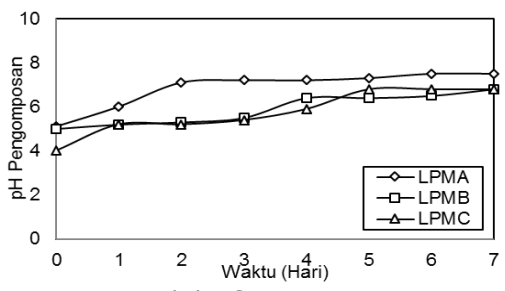

(c) Sekam padi

Gambar 3. Perubahan $\mathrm{pH}$ pengomposan

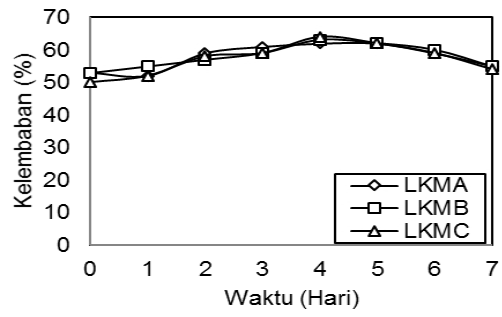

(a) Kulit buah kopi

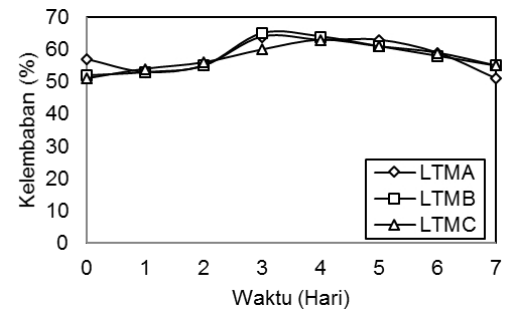

(b) Tangkai daun tembakau

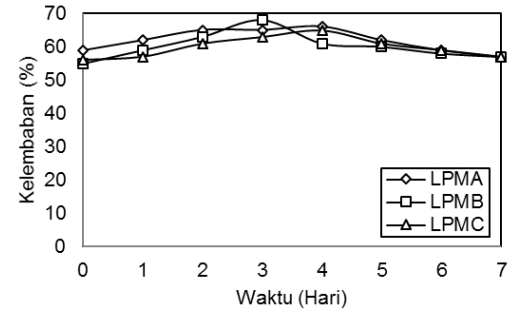

(c) Sekam padi

Gambar 4. Perubahan kelembaban pengomposan

Tabel 2. Komparasi kompos blok terhadap variabel pengomposan

\begin{tabular}{lcccccccccc}
\hline Variabel & \multicolumn{10}{c}{ Perlakuan Jenis dan Ukuran Bahan } \\
$\begin{array}{l}\text { Pengomposan } \\
\quad \text { Proses }\end{array}$ & Limbah Kulit Kopi (LK) & \multicolumn{1}{c}{ Limbah Batang Tembakau (LT) } & Limbah Sekam Padi (LP) \\
Pengomposan & 10 & 40 & 80 & 10 & 40 & 80 & 10 & 40 & 80 \\
& mesh & mesh & mesh & mesh & mesh & mesh & mesh & mesh & mesh \\
\hline Suhu $\left({ }^{\circ} \mathrm{C}\right)$ & 38,3 & 34,0 & 35,1 & 38,1 & 34,3 & 38,2 & 42,0 & 41,1 & 38,0 \\
pH & 7,8 & 7,5 & 7,5 & 7,3 & 7,5 & 7,9 & 7,5 & 6,8 & 6,8 \\
Kelembaban $(\%)$ & 62,0 & 63,0 & 64,0 & 64,0 & 65,0 & 63,0 & 66,0 & 68,0 & 65,0 \\
\hline
\end{tabular}

\subsubsection{Kelembaban}

Kelembaban optimum pengomposan yaitu bernilai $40-60 \%$ yang selajutnya kembali mengalami penurunan ${ }^{(23)}$. Perubahan kelembaban yang dialami sampel limbah kulit kopi, limbah tangkai daun tembakau, dan limbah sekam padi dapat dilihat pada Gambar 4. Adapun rentang nilai kelembaban kompos dari limbah kulit kopi (LK), limbah tangkai daun tembakau (LT), dan sekam padi (LP) secara berurutan sebesar 52\% - 63\%; 53,33\% $63,33 \%$; dan $56,67 \%-65,33 \%$.

Pada proses pengomposan terjadi penurunan serta kenaikan kelembaban yang disebabkan karena perbedaan cuaca lingkungan yang tidak stabil. Konsekuensi ini timbul akibat pegunaan bahan yang didekomposisi tidak terlalu banyak. Dengan demikian timbunan yang terbentuk tidak terlalu padat. Hasil kajian Novita et al.(17), kelembaban lingkungan berpotensi mempengaruhi proses pengomposan bahan organik. Apabila kondisi kelembaban selama proses pengomposan kurang dari kelembaban optimum (40\% - 60\%) maka akan mengakibatkan proses pengomposan berlangsung lebih lambat. Akan tetapi apabila kelembaban lebih besar dari kelembaban optimum maka akan mengakibatkan volume udara berkurang, hara akan tercuci serta menurunnya aktivitas mikroorganisme sehingga akan memperlambat proses pengomposan serta menjadikan kondisi kompos menjadi anaerobik ${ }^{(26)}$.

\subsubsection{Komparasi Pelakuan (Ukuran dan Bahan) Terhadap Parameter Pengomposan}

Berdasarkan hasil uji statistik, kompos blok yang paling baik terhadap parameter suhu pengomposan adalah sekam padi dengan ukuran 10 mesh bersuhu 29 - $42{ }^{\circ} \mathrm{C}$. Sekam 
padi menjadi pemasok subtrat yang cukup tinggi berupa C-Organik dan Nitrogen (27). Sehingga diduga proses perombakan bahan organik oleh mikroorganisme berjalan optimal dan mampu menimbulkan perubahan suhu pada bahan. Hal ini ditunjukan dengan hasil uji duncan perbedaan sampel (bahan) terhadap suhu pengomposan menunjukkan nilai berbeda nyata dengan $\alpha 5 \%$. Pengomposan sampel pada hari ke tiga, memiliki perbedaan yang nyata yaitu pada limbah sekam padi. Berdasarkan hasil uji statistik ANOVA diketahui bahwa nilai $\mathrm{F}$ hitung 2,948 $\leq \mathrm{F}$ Tabel 3,14 maka $\mathrm{H} 0$ diterima dan $\mathrm{H} 1$ ditolak atau tidak ada perbedaan yang signifikan antara perlakuan pengecilan ukuran (mesh) terhadap suhu pengomposan. Pada ketiga sampel diketahui bahwa sampel yang memiliki perbedaan yang nyata yaitu pada limbah sekam padi. Hal tersebut dapat diketahui berdasarkan hasil uji statistik Duncan yag menunjukkan hasil perbedaan yang nyata.

Kompos blok paling baik terhadap parameter proses pengomposan $\mathrm{pH}$ yaitu limbah batang tembakau ukuran 80 mesh dengan nilai $\mathrm{pH} 4-7,9$ dan cenderung netral di hari ke 7 dekomposisi. pH pupuk mendekati netral dan tidak bersifat asam lebih cepat oleh tanaman dan mengurangi keasaman tanah ${ }^{(25)}$. Berdasarkan hasil uji normalitas diketahui data parameter proses pengomposan $\mathrm{pH}$ tidak terdistribusi normal sehingga dilanjutkan dengan uji chi square. Hasil uji statistik chi square dengan a $5 \%$ diketahui nilai chi square hitung < titik kritis maka $\mathrm{H} 0$ diterima dan $\mathrm{H} 1$ ditolak. Artinya jenis bahan dan perlakuan pengecilan ukuran (mesh) tidak ada perbedaan terhadap $\mathrm{pH}$ pengomposan.

Kompos blok yang paling baik terhadap parameter kelembaban pengomposan adalah limbah sekam padi ukuran 40 mesh dengan nilai kelembaban $68 \%$ yang selajutnya kembali mengalami penurunan (23). Kesimpulan ini didukung oleh hasil uji statistik. Hasil uji statistik ANOVA dengan a $5 \%$ diketahui bahwa nilai $F$ hitung 3,857 > F tabel 3,14 maka H0 ditolak dan $\mathrm{H} 1$ diterima. Dengan kata lain terdapat perbedaan yang signifikan jenis bahan terhadap kelembaban pengomposan. Berdasarkan hasil Uji Duncan perbedaan sampel (bahan) terhadap kelembaban pengomposan menunjukkan nilai berbeda nyata dengan a $5 \%$. Nilai kelembaban pada ketiga sampel diketahui bahwa sampel yang memiliki perbedaan yang nyata yaitu pada limbah sekam padi. Kemudian hasil uji statistik ANOVA dengan a $5 \%$ diketahui bahwa nilai $F$ hitung $0,433 \leq \mathrm{F}$ Tabel 3,14 maka H0 diterima dan $\mathrm{H} 1$ ditolak. Dengan kata lain tidak ada perbedaan yang signifikan antara perlakuan pengecilan ukuran (mesh) dengan kelembaban pengomposan.

\subsection{Komparasi Laju Pertumbuhan Vegetatif Tanaman pada Masing-Masing Kompos Blok}

\subsubsection{Laju Tinggi Tanaman}

Merujuk pada Gambar 5. dapat diketahui laju pertumbuhan tinggi tanaman tertinggi yaitu pada sampel LPMB (Limbah Sekam Padi Ukuran 40 mesh) dengan nilai $0,35 \mathrm{~cm} /$ hari. Limbah sekam padi memiliki kandungan ratio $\mathrm{C} / \mathrm{N}$ yang lebih tinggi dibandingkan dengan sampel lainnya. Laju tinggi tanaman terendah terletak pada sampel LTMA (Limbah Batang Tembakau Ukuran 10 mesh) dan LTMC (Limbah Batang Tembakau Ukuran 80 mesh) dengan nilai yang sama yaitu $0,021 \mathrm{~cm} /$ hari.

Pertumbuhan tinggi tanaman juga didukung oleh ketersediaan unsur $\mathrm{N}$ pada media tanam. Nitrogen berperan dalam merangsang pertumbuhan tanaman secara keseluruhan, khususnya batang, cabang, dan daun (28). Berdasarkan hasil uji pada rasio $\mathrm{C} / \mathrm{N}$ tertinggi terdapat pada sampel limbah sekam padi. Hal tersebut sesuai dengan hasil pengujian laju tinggi tanaman cabai. Laju tertinggi pada kompos blok limbah sekam padi ukuran 40 mesh.

\subsubsection{Laju Jumlah Daun}

Laju jumlah daun tertinggi terdapat pada sampel limbah sekam padi 40 mesh dengan laju 0,025 . Kondisi ini dapat dilihat pada Gambar 6 . Sama halnya dengan laju tinggi tanaman, laju jumlah daun pada sampel limbah batang tembakau juga menunjukkan nilai terendah yaitu 10 mesh dengan laju 0,011 daun/hari. Hasil pengamatan laju jumlah daun diketahui bahwa laju jumlah daun berbanding lurus dengan tinggi tanaman dimana semakin tinggi tanaman maka jumlah daun semakin meningkat. Semakin tinggi tanaman maka akan menghasilkan daun yang semakin banyak ${ }^{(29)}$. Laju jumlah daun dipengaruhi oleh kandungan $\mathrm{N}$ dalam media tanam. Kandugan $\mathrm{N}$ tersebut akan dipengaruhi $\mathrm{C} / \mathrm{N}$. Hasil pengujian nilai $\mathrm{C} / \mathrm{N}$ kompos blok tertinggi terdapat pada sampel limbah sekam padi. Selain itu laju jumlah daun juga dipengaruhi oleh masa atau pertumbuhan daun. Fenomena ini berupa beberapa daun yang pertama kali muncul mengalami penguningan dan pengguguran daun. Kondisi ini berpotensi menurukan jumlah daun. Hal tersebut akan menurunkan jumlah daun, konsekuensinya tanaman sehingga akan berdampak terhadap perubahan laju jumlah daun.

\subsubsection{Laju Luas Daun}

Berdasarkan data pada Gambar 7. diketahui bahwa laju luas daun tertinggi adalah sampel 
limbah sekam padi 80 mesh dengan nilai 0,032 $\mathrm{cm}^{2} /$ hari. Adapun laju luas daun terendah yaitu pada sampel limbah tembakau 10 mesh dan 80 mesh dengan nilai yang sama $0,008 \mathrm{~cm}^{2} /$ hari.

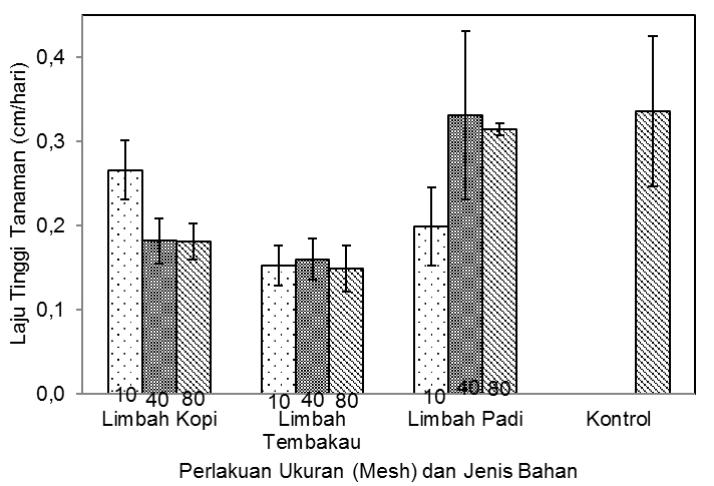

Gambar 5. Hubungan perlakuan dengan laju pertumbuhan tinggi tanaman

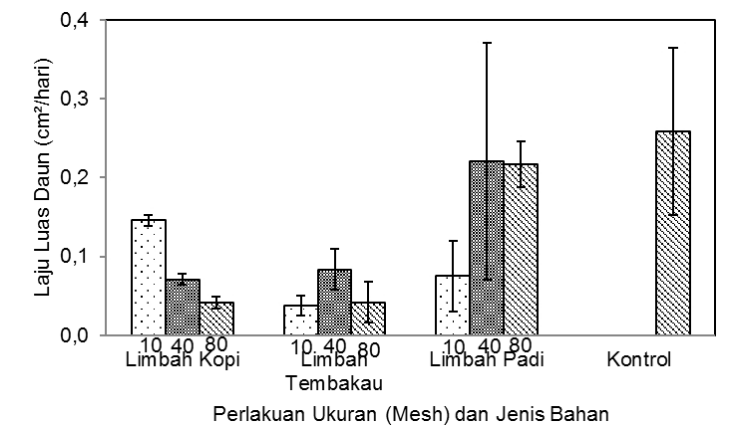

Gambar 7. Hubungan perlakuan dengan laju pertumbuhan luas daun

Hasil penelitian diperoleh sampel limbah sekam padi memiliki kandungan $\mathrm{C} / \mathrm{N}$ tertinggi dibandingkan sampel lain sehingga memiliki laju pertubuhan yang relatif besar. Merujuk pada hasil penelitian Setyati et al. ${ }^{(30)}$, faktor yang mempengaruhi pertambahan luas daun salah satunya yaitu faktor lingkungan seperti suplay unsur hara, suhu, kelembaban, keasaman tanah, faktor biotik, dan energi radiasi. Sampel limbah sekam padi memperoleh intensitas radiasi yang cukup dibandingkan dengan sampel lain. Fenomena ini terjadi akibat letak sampel di bawah naungan sehingga terdapat perbedaan penyinaran antar sampel.

\subsubsection{Laju Diameter Batang}

Laju diameter batang tertinggi yaitu limbah sekam padi 10 mesh dengan nilai laju 0,042 $\mathrm{cm} /$ hari. Adapun laju terendah yaitu pada limbah batang tembakau 10 mesh dengan nilai laju $0,026 \mathrm{~cm} /$ hari. Informasi terkait laju diameter batang tanaman dapat dilihat pada Gambar 8. Tingginya nilai laju diameter batang pada sampel sekam padi diduga karena nilai rasio $\mathrm{C} / \mathrm{N}$ yang lebih optimum daripada limbah lainnya.
Luas daun dipengaruhi oleh unsur hara terutama N. Unsur $\mathrm{N}$ tersebut akan mempengaruhi nilai $\mathrm{C} / \mathrm{N}$ dalam kompos.

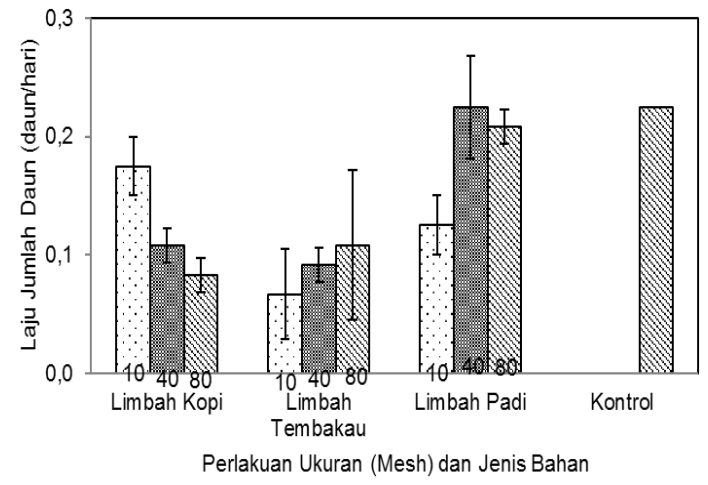

Gambar 6. Hubungan perlakuan dengan laju jumlah daun tanaman

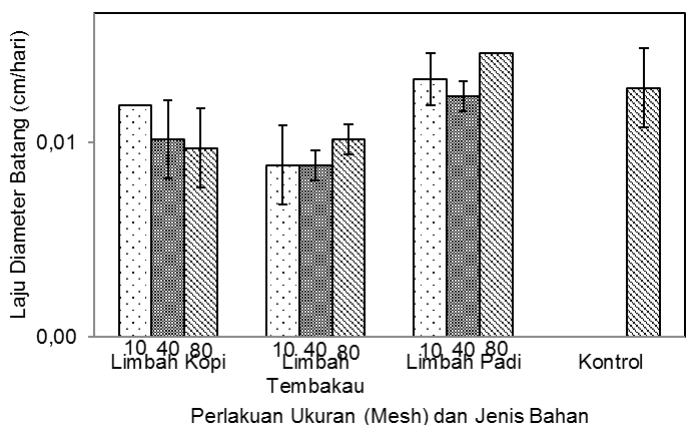

Gambar 8. Hubungan perlakuan dengan laju pertumbuhan diameter batang

Selain itu dipengaruhi oleh penyinaran atau radiasi. Kompos blok dari sampel limbah sekam padi memperoleh penyinaran yang lebih baik dibandingkan dengan sampel lain sehingga akan melancarkan proses fotosintesis. Jika proses fotosintesis suatu tanaman berjalan dengan baik maka akan membantu proses pertumbuhan vegetatif tanaman. Semakin cepat fotosintesis maka fotosintat yang dihasilkan akan memperbesar ukuran lingkar batang ${ }^{(30-32)}$.

\subsubsection{Komparasi efektivitas Kompos Terhadap Parameter Pertumbuhan Vegetatif Tanaman}

Kompos blok yang paling efektif terhadap parameter laju tinggi tanaman, jumlah daun, dan luas daun adalah limbah sekam padi ukuran 40 mesh. Hasil ini didukung oleh hasil uji statistik. Hasil uji statistik berupa hasil uji ANOVA dengan a $5 \%$ diketahui bahwa nilai $F$ hitung 1,397 $\leq F$ tabel 3,26 maka HO diterima. Dengan kata lain tidak ada perbedaan yang signifikan sampel atau jenis bahan terhadap laju tinggi tanaman. Perbedaan perlakuan pengecilan ukuran (mesh) terhadap suhu pengomposan menunjukkan nilai $\mathrm{F}$ hitung $1,073 \leq \mathrm{F}$ tabel 3,26 maka $\mathrm{H} 0$ diterima. 
Dengan kata lain tidak ada perbedaan yang signifikan antara perlakuan dengan laju tinggi tanaman.

Berdasarkan hasil Uji ANOVA diketahui data laju jumlah daun tidak terdistribusi normal sehingga dilanjutkan dengan uji chi square. Hasil uji chi square dengan a $5 \%$ diketahui bahwa nilai chi square hitung < chi square titik kritis maka $\mathrm{H} 0$ diterima dan $\mathrm{H} 1$ ditolak. Artinya tidak ada hubungan atau perbedaan yang signifikan baik antara sampel atau jenis bahan terhadap laju jumlah daun maupun perlakuan pengecilan ukuran (mesh) terhadap laju jumlah daun. Hasil Uji ANOVA diketahui data laju luas daun tidak terdistribusi normal sehingga dilanjutkan dengan uji chi square. Adapun hasil uji statistik chi square dengan a $5 \%$ diketahui bahwa nilai chi square hitung < titik kritis maka $\mathrm{HO}$ diterima dan $\mathrm{H} 1$ ditolak. Artinya tidak ada hubungan atau perbedaan yang signifikan baik antara sampel atau jenis bahan terhadap laju jumlah daun maupun perlakuan pengecilan ukuran (mesh) terhadap laju jumlah daun. Dengan demikian kompos blok yang paling efektif dalam laju diameter batang memang sekam padi akan tetapi berbeda ukuran.

Kompos blok yang paling efektif terhadap parameter laju luas daun yaitu limbah sekam padi ukuran 40 mesh. Berdasarkan hasil uji statistik ANOVA dengan a $5 \%$ diketahui nilai perbedaan jenis bahan terhadap laju diameter batang menunjukkan nilai $\mathrm{F}$ hitung 4,782 > F tabel 3,26 maka $\mathrm{H} 1$ diterima ada perbedaan yang signifikan antara jenis bahan dengan laju luas daun. Berdasarkan hasil uji Duncan antara jenis bahan dengan laju luas daun diketahui sampel paling berpengaruh yaitu limbah sekam padi. Perbedaan perlakuan pengecilan ukuran (mesh) terhadap laju luas daun yaitu menunjukkan nilai $F$ hitung $2,240 \leq F$ tabel 3,26 maka $\mathrm{H} 0$ diterima dan $\mathrm{H}_{1}$ ditolak atau tidak ada perbedaan yang signifikan antara perlakuan pengecilan ukuran (mesh) terhadap laju luas daun.

Kompos blok yang paling efektif terhadap parameter laju diameter batang yaitu limbah sekam padi ukuran 10 mesh. Berdasarkan hasil uji statistik ANOVA dengan a $5 \%$ diketahui nilai perbedaan jenis bahan terhadap laju diameter batang menunjukkan nilai $F$ hitung $2,813 \leq F$ tabel 3,26 maka $\mathrm{H} 0$ diterima dan $\mathrm{H} 1$ ditolak atau tidak ada perbedaan yang signifikan antara jenis bahan dengan laju diameter batang. Perbedaan perlakuan pengecilan ukuran (mesh) terhadap laju diameter batang yaitu menunjukkan nilai $F$ hitung $0,971 \leq \mathrm{F}$ tabel 3,26 maka $\mathrm{H} 0$ diterima dan $\mathrm{H} 1$ ditolak, atau tidak ada perbedaan yang signifikan antara perlakuan pengecilan ukuran (mesh) terhadap laju diameter batang.

\section{KESIMPULAN}

Kesimpulan dari hasil penelitian yang telah dipaparkan yaitu limbah yang memiliki kandungan rasio $\mathrm{C} / \mathrm{N}$ tertinggi sebagai bahan baku kompos yaitu limbah sekam padi dengan nilai rasio $\mathrm{C} / \mathrm{N}$ 16,21 dengan kandungan $\mathrm{C}$ $12,32 \%$ dan $N$ 0,76\%. Kompos dari sekam padi memiliki nilai $\mathrm{C} / \mathrm{N}$ yang paling tinggi sebesar 19,71. Bahan yang memiliki perbedaan yang nyata pada parameter pengomposan suhu dan kelembaban dimana perbedaan paling kuat juga terletak pada sampel limbah sekam padi. Semua sampel mecapai nilai standar parameter pengomposan. Perlakuan ukuran bahan memiliki perbedaan yang nyata pada parameter laju pertumbuhan vegetatif tanaman. Akan tetapi perlakuan variasi ukuran bahan tidak berbeda nyata terhadap parameter laju pertumbuhan vegetatif tanaman. Kompos blok paling efektif terhadap parameter laju pertumbuhan vegetatif tanaman adalah kompos blok dari limbah sekam padi 40 mesh. Asumsi ini didukung oleh uji statistik yang menunjukkan perbedaan yang signifikan dari perlakuan tersebut terhadap tiga parameter vegetatif tanaman. Parameter tersebut yaitu laju tinggi tanaman, laju jumlah daun, dan luas daun.

\section{PERSANTUNAN}

Ucapan terima kasih terkhusus diberikan kepada Zakina Romadona, S.T., yang telah banyak membantu dalam bentuk tenaga dan pikiran pada penelitian ini. Ucapan terima kasih juga diberikan kepada Fakultas Teknologi Pertanian Universitas Jember dan Kawasan Usaha Perkebunan Kopi (KUPK) Sidomulyo Kabupaten Jember yang telah memberikan dukungan berupa fasilitas pendukung untuk penyelesaian penelitian ini. Selanjutnya, ucapan terima kasih juga disampaikan kepada para reviewer yang telah memberikan umpan balik agar penulisan hasil penelitian ini lebih baik.

\section{DAFTAR PUSTAKA}

1. Kementerian Pertanian. (2019). Statistik perkebunan Indonesia-kopi: Jakarta. http://ditjenbun.pertanian.go.id/?publikasi=buk u-publikasi-statistik-2018-2020 [Diakses pada 14 November 2020].

2. Kementerian Pertanian. (2019). Statistik Perkebunan Indonesia-tembakau: Jakarta. http://ditjenbun.pertanian.go.id/?publikasi=buk u-publikasi-statistik-2018-2020 [Diakses pada 14 November 2020].

3. Kementerian Pertanian Republik Indonesia. (2020). Data lima tahun terakhir sub-sektor kementerian pertanian: Jakarta. https://www.pertanian.go.id/home/?show=pag 
e\&act=view\&id=61 [Diakses pada 14 November 2020].

4. Novita, E. Fathurrohmah, A., dan Pradana, H. A. (2018). Pemanfaatan kompos blok limbah kulit kopi sebagai media tanam. Jurnal Agrotek, 2(2), 61-72.

5. Hertanto, S. C. (2014). Merenda Laba dari Limbah Tembakau. https://puslitklaten. wordpress.com/2014/03/05/merenda-labadari-limbah-tembakau/ [Diakses pada 20 Maret 2018].

6. Widowati, S. (2011). Pemanfaatan hasil samping penggilingan padi dalam menunjang sistem agro industri di pedesaan. Buletin AgroBio, 4(1), 33-38.

7. Yunita, L., Marsyudi, E., dan Kasimin, S. (2016). Pola pemanfaatan limbah pertanian untuk usahatani di Kabupaten Pidie Provinsi Aceh. Jurnal IImiah Mahasiswa Pertanian, 1(1), 369-375. doi: 10.17969/jimfp.v1i1.1377.

8. Tirtosarto, S. dan Murdiyati, A. S. (2010). Kandungan kimia tembakau dan rokok. Buletin Tanaman Tembakau, Serat, dan Minak Industri, 2(1), 33-43. doi: 10.21082/bultas.v2n1.2010.33-44.

9. Demir, Z. dan Gulser, C. (2015). Effect of rice husk compost application on soil quality parameter in greenhouse conditions. Eurasian Journal Soil Science, 4(3), 185-190. doi: 10.18393/ejss.2015.3.185-190.

10. Setyorini, D., Saraswati, R., dan Anwar, E.K. (2006). Pupuk organik dan pupuk hayati: Bogor: Balai Penelitian Tanah. ISBN 9789799474575.

11. Golueke, C. G. (1972). Composting - a study of the process and its principles: Rodale Press, Inc. Emmaus, USA.

12. Diaz, L. F., Bertoldi, M., Bidlingmaier, W., dan Stentiford, E. (2007). Compost science and technology: Elsevier. UK.

13. Pandebesie, E.S., dan Rayuanti, D. (2013). Pengaruh penambahan sekam pada proses pengomposan sampah domestik. Jurnal Lingkungan Tropis, 2013, 6(1), $\quad 31-40$.

14.Zulkarnain, M., Prasetya, B., dan Soemarno. (2013). Pengaruh kompos, pupuk kandang, dan custom-bio terhadap sifat tanah, pertumbuhan, dan hasil tebu (Saccharum officinarum I.) pada entisol di Kebun NgrakahPawon, Kediri. Indonesian Green Technology Journal, 2(1), 45-52.

15. Kurnia, V. C., Sumiyati S, dan Samudro G. (2017). Pengaruh kadar air terhadap hasil pengomposan sampah organik dengan metode open windrow. Jurnal Teknik Mesin, 6 , 119-123.

16.Darwis, V. dan Rachman, B. (2013). Potensi pengembangan pupuk organik insitu mendukung percepatan penerapan pertanian organik. Forum Penelitian Agro Ekonomi, 31(1), 51-56. doi: 10.21082/fae.v31n1.2013.51-65.

17. Novita, E., Andriyani, I., Romadona, Z. dan Pradana, A. P. (2020). Pengaruh variasi jenis dan ukuran limbah organik terhadap kadar air kompos blok dan pertumbuhan tanaman cabai. Jurnal Presipitasi: Media Komunikasi dan Pengembangan Teknik Lingkungan, 17(1), 19-28. doi: 10.14710/presipitasi.v17i1.19-28.

18. Peraturan Menteri Pertanian No. 70 Tahun (2011). Pupuk organik, pupuk hayati dan pembenah tanah. 25 Oktober 2011.

19. Sitompul, S. M., dan Guritno, B. (1995). Analisis pertumbuhan tanaman: Yogyakarta: Gadjah Mada University Press.

20. Ledhyane, I. H. (2012). Analisis ragam dan rancang acak lengkap. http://ledhyane. lecture.ub.ac.id/files/2012/11/RAL.pdf [Diakses pada 20 Maret 2018].

21. Khalil, M. (2016). Pengaruh pemberian limbah kulit kopi (Coffea sp.) amoniasi sebagai pakan alternatif terhadap pertumbuhan bobot ayam broiler. Jurnal IImiah Mahasiswa Pendidikan Biologi 1(1): 119-130. http://jim.unsyiah.ac.id/pendidikanbiologi/article/view/357.

22. Purnamasari, F. (2016). Pengaruh penyiraman hasil biodegradasi daun oleh keong mas terhadap pertumbuhan vegetatif tanaman cabai rawit.Jurnal Biologi, 5(4), 1023.

23. Widarti, B.N., Wardhini, W.K., dan Sarw, E. 2015. Perbedaan rasio $\mathrm{C} / \mathrm{N}$ bahan baku pada pembuatan kompos dari kubis dan kulit pisang. Jurnal Integrasi Proses, 5(2), 75-80. doi: 10.36055/jip.v5i2.200.

24. Sahwan, F. L. (2012). Analisis proses komposting pada pengelolaan sampah berbasis masyarakat skala kawasan (studi kasus di Kota Depok). Jurnal Teknologi Lingkungan, 13(3), 253-260. doi: 10.29122/jtl.v13i3.1394.

25. Suswatanti, E. P. S. dan Widiyaningrum, P. (2017). Pemanfaatan MOL limbah sayur pada proses pembuatan kompos. Jurnal MIPA, 40(1), 1-6.

26. Gaur, A. C. (1982). Improving soil fertility trough organic recycling a. manual of rural 
composting project field document No. 15 FAO/UNDP Regional Project RAS/75/004.

27. Thiyageshwari, S., Gayathri, P., Krishnamoorthy, R., Anandham, R. dan Diby Paul. (2018). Exploration on rice husk compost as an alternate organic manure to enhance the productivity of blackgram in Typic haplusalf and Typic rhodustalf. Intenational Journal of Environmental Research and Public Health, $\quad 15(2), \quad 358 . \quad$ doi: 10.3390/ijerph15020358.

28. Gojon, A. (2017). Nitrogen nutrition in plants: rapid progress and new challenges. Journal of Experimental Botany, 68(10), 2457-2462. doi: 10.1093/jxb/erx171

29. Solikin. (2013). Pertumbuhan vegetatif dan generatif Stachytarpeta Jamaicensis (L.) Vahl. Proceeding Biology Education Conference, 5(52), 1-6.
30. Setyati, Y. H., Anwar, S. dan Slamet, W. (2013). Karakteristik fotosintetik dan serapan fosfor hijauan alfalfa pada tinggi pemotongan dan pemupukan nitrogen yang berbeda. Animal Agriculture Journal, 2(1), 86-96.

31. Sayekti, R. S., Prajitno, D. dan Indadewa, D. (2016). Pengaruh pemanfaatan pupuk kandang dan kompos terhadap pertumbuhan kangkong (Ipomea retans) dan lele dumbo (Clarias gariepinus) pada system akuaponik. Jurnal Teknologi Lingkungan, 17(2), 108-117. doi:10.29122/jtl.v17i2.111

32. Nurcahya, A. O., Herlina, N. dan Guritno, B. 2017. Pengaruh macam pupuk organik dan waktu aplikasi terhadap pertumbuhan dan hasil jagung manis (Zea mays saccharate Sturt). Jurnal Produksi Tanaman, 5(9), 14761482. 